Przemysław Sznurkowski*

\section{Kompendium wiedzy o współczesnych fenomenach kultury krajów niemieckojęzycznych}

DOI: http://dx.doi.org/10.12775/LC.2019.044
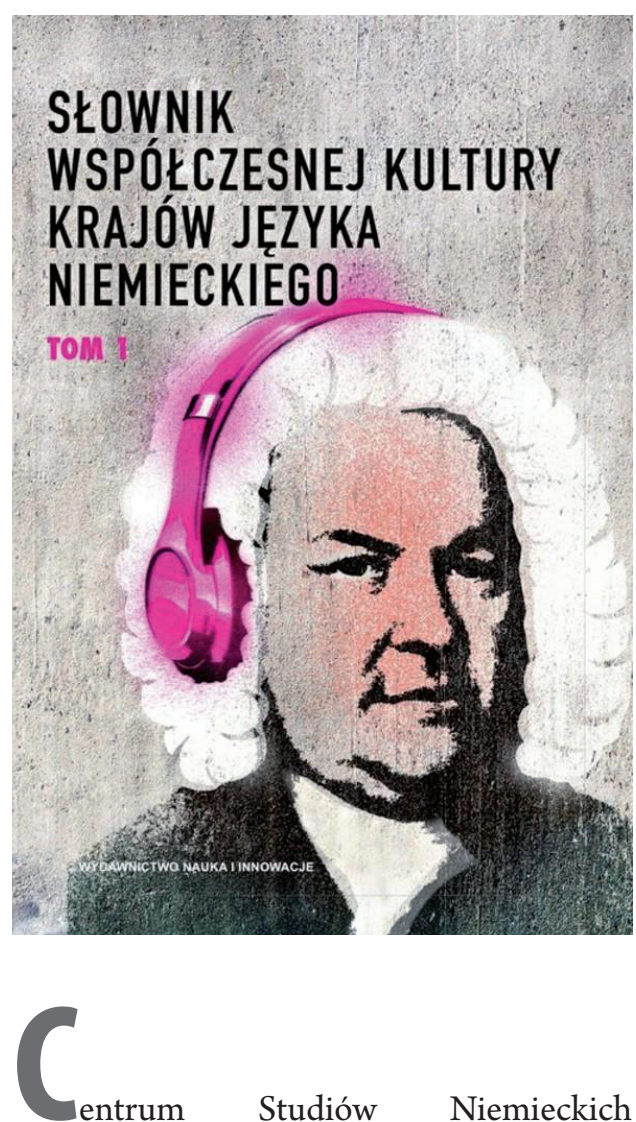

entrum Studiów Niemieckich i Europejskich im. Willy'ego Brandta Uniwersytetu Wrocławskiego po raz ko-

"Adiunkt na Uniwersytecie Humanistyczno-Przyrodniczym im. Jana Długosza w Częstochowie, germanista, literaturoznawca. Zajmuje się współczesną prozą niemieckojęzyczną, najnowszą literaturą niemiecko-żydowską i polsko-niemieckim pograniczem.

E-mail: p.sznurkowski@ujd.edu.pl | ORCID: 00000002-6137-9005. lejny może poszczycić się ciekawą publikacją germanistyczną - pod redakcją prof. Krzysztofa Ruchniewicza i prof. Marka Zybury ukazal się bowiem pierwszy tom Stownika wspótczesnej kultury krajów języka niemieckiego. Redaktorzy omawianej publikacji to niemcoznawcy z ogromnym dorobkiem naukowym, naukowcy o ugruntowanej pozycji w środowisku germanistycznym i politologicznym. Do wspólpracy przy tworzeniu haseł zaprosili również nie tylko wielu zasłużonych dla nauki kulturoznawców, historyków, literaturoznawców, ale także młodszych adeptów sztuki badawczej.

Redaktorzy słownika zwracają we Wstępie uwagę na pewną ewolucję w postrzeganiu historii kultury ostatnich kilkudziesięciu lat. Słusznie sygnalizują, że była traktowana wcześniej w środowisku historycznym jako mniej istotna - m.in. ze względu na „hermetyzację tradycyjnych badań historycznych, nie tylko nieaspirujących do, lecz wręcz stroniących od całościowego oglądu danej kultury czy kultur" (s. 5). Co zatem stoi za sukcesem historii kultury, cieszącej się w ostatnich dekadach ożywionym zainteresowaniem badaczy? Krzysztof Ruchniewicz i Marek Zybura uzasadniają triumf tej dziedziny humanistyki m.in. „ofensywnym otwarciem na problematykę kulturową" innych dyscyplin naukowych, przenikających się i inspirujących wzajemnie, wśród których wymieniają przykładowo socjologię, psychologię, etnografię, antropologię, nauki polityczne, geografię czy ekonomię (s. 5). Powołując się na tekst What is Cultural History Petera Burke'a z roku 2004, redaktorzy słownika zauważają poza tym zmianę $\mathrm{w}$ obecnym postrzeganiu otaczającego nas świata, wynikającą z „oswajania” tzw. kultury wysokiej w osobliwy sposób - jako przykład podają nieszokujące już dziś dyskursy dotyczące „kultury śmierci” czy „kultury ogródków działkowych" (s. 5). 
We Wstępie redaktorzy jasno określają główną motywację, jaką kierowali się przy konstruowaniu słownika - ich zamiarem było stworzenie „kompendium o charakterze słownikowym”, zawierającym „szybką, skondensowaną informację". Wspominają jednocześnie o bardzo wartościowych i cieszących się sporym uznaniem w środowisku germanistycznym opracowaniach ostatnich dwóch dekad, które jednak miały $\mathrm{w}$ założeniach nieco inny charakter - raczej przeglądowy i syntezujący. Chodzi tu m.in. o następujące pozycje: Dzieje kultury niemieckiej, opracowane przez Czesława Karolaka, Wojciecha Kunickiego i Huberta Orłowskiego, Kultura zjednoczonych Niemiec Zbigniewa Mazura, Huberta Orłowskiego i Marii Wagińskiej-Marzec, Niemcy wspótczesne. Zarys encyklopedyczny, wydane przez Instytut Zachodni w Poznaniu. Zespół autorski zrezygnował poza tym $\mathrm{z}$ umieszczenia haseł biograficznych - uznał je bowiem nie tylko za zbyteczne ze względu na możliwości, jakie daje Wikipedia, ale także ze względu na wcześniejszą publikację pod redakcją Huberta Orłowskiego Stownik twórców kultury niemieckojęzycznej z roku 1999. Należy tu dodać, iż w roku 1996 ukazała się inna ważna pozycja pod redakcją Marka Zybury: Pisarze niemieckojęzyczni XX wieku. Leksykon encyklopedyczny PWN, która również stanowi kompetentne opracowanie biograficzne.

Metodologia, jaką kierowali się twórcy słownika przy jego konstrukcji i doborze hasel, wpisuje się $\mathrm{w}$ pewnym sensie w cytowaną we Wstępie definicję kultury, sformułowaną w 1982 roku podczas odbywającego się w Mexico City światowego kongresu UNESCO, który był związany z polityką kulturalną MONDIACULT. Zgodnie z zaproponowaną definicją, potwierdzającą „cultural turn”, kulturę należy traktować „jako zespół cech duchowych i materialnych, intelektualnych i uczuciowych, charakteryzujących społeczeństwo lub grupę społeczną" - kultura powinna obejmować „oprócz sztuki i literatury, sposoby życia, formy wzajemnego współżycia, systemy wartości, tradycje i przekonania” (por. s. 6). Tak też kulturę zdają się rozumieć redaktorzy omawianego tomu. $\mathrm{Na}$ jego zawartość składa się 355 haseł, ułożonych alfabetycznie, a także indeks osobowy oraz indeks tematyczny, które znacznie ułatwiają odnalezienie określonych informacji szczegółowych. Indeks tematyczny podzielony został na 13 kręgów znaczeniowych, skupiających hasła odnoszące się m.in. do literatury, kina, teatru, rynku wydawniczego, sztuk plastycznych, instytucji kultury, polityki, historii najnowszej, ale także te związane z życiem codziennym i obyczajami. Autorzy określili rok 1945 jako cezurę w dziejach współczesnej kultury krajów niemieckiego obszaru językowego, co oczywiście jest zrozumiałe. Podział tematyczny pomaga czytelnikowi nie tylko uporządkować treści wynikające $\mathrm{z}$ danego kręgu tematycznego, ale może stanowić istotny impuls do dalszych poszukiwań badawczych.

Biorąc pod uwagę mnogość projektowanych haseł i ich ewoluujący charakter, Krzysztof Ruchniewicz i Marek Zybura zdecydowali się na przyjęcie tzw. systemu holenderskiego, czyli zakładającego publikację wielotomową pod wspólnym tytułem, w której obowiązuje układ alfabetyczny hasel, będących uzupełnieniem i kontynuacją wcześniejszych tomów (zob. s. 6-7). Zgodnie z założeniami kolejny tom jest planowany za około 2-3 lata.

Już trafnie dobrana grafika na okładce, przedstawiająca znaną z obrazu Eliasa Gottloba Haussmanna postać Johanna Sebastiana Bacha, tym razem $\mathrm{z}$ różowymi słuchawkami na uszach, zdradza potencjalnego odbiorcę słownika: pozycja ta może być skierowana m.in. do czytelnika 
młodszej generacji, zainteresowanego fenomenami kultury i literatury niemieckiej czy wydarzeniami z najnowszej historii Niemiec i stosunków polsko-niemieckich. Toteż w pierwszej kolejności powinna trafić do studentów germanistyki lub niemcoznawstwa, chociaż z całym przekonaniem można polecić tę publikację każdemu, kto chciałby po prostu bliżej poznać kulturę krajów niemieckiego obszaru językowego. Ruchniewicz i Zybura dostrzegają także potrzebę skłonienia polskiego czytelnika do „refleksji nad niemieckim kapitałem i profilem kulturowym", co - zdaniem redaktorów - jest niedoceniane w obecnym polskim dyskursie, zdominowanym „przez problematykę tożsamości państwowej Niemiec" (s. 7).

Ze względu na dużą liczbę haseł tworzących publikację nie sposób odnieść się rzecz jasna - do wszystkich z nich. Należy podkreślić, iż hasła te zostały opracowane w sposób kompetentny i ciekawy dla czytelnika - nie mamy tu do czynienia tylko i wyłącznie z przytaczaniem suchych faktów, ale przede wszystkim - i tu największa wartość publikacji - z licznymi ciekawostkami związanymi z powojennym społeczeństwem krajów niemieckojęzycznych. Wiele haseł (dotyczących np. literatury austriackiej, szwajcarskiej, literatury niemieckiej po 1945 roku czy literaturoznawstwa feministycznego) zostało opracowanych kompleksowo, mimo że ich autorzy postawili przed sobą niełatwe zadanie opisania najważniejszych fenomenów literackich w tak kompaktowej formie. Oczywiście, czytelnik może w niektórych przypadkach odnieść wrażenie nieco skrótowego opisu pewnych pojęć, ale trzeba zauważyć, iż wiele informacji uzupełniających zawarto $\mathrm{w}$ innych hasłach. Liczne odniesienia do nich - pisane wielkimi literami - pozwalają sprawnie odszukać w słowniku dane hasło i poznać szerszy kontekst tematyczny.
Przenikanie się pojęć świadczy o tym, iż współczesna kultura nie składa się jedynie z ugruntowanych w świadomości społecznej typowych kręgów znaczeniowych, ale jest wynikiem nakładania się na siebie różnych dyscyplin. $\mathrm{Z}$ takiego też założenia zdają się wychodzić redaktorzy omawianego tomu - zaproponowane przez nich hasła są w pewnej mierze odzwierciedleniem ważnych fenomenów socjologicznych, budujących lub bezpośrednio wpływających na kulturę. Rzecz jasna niektórych czytelników mogą zaskoczyć wybrane pojęcia, np. Beate Uhse, Biożywność, Brojlery, Drzewo Roku, Dzień Kobiet, Doping, Figurki Berty Hummel, „Ötzi”, Playmobil lub te dotyczące wystaw ogrodniczych, jednak należy je traktować jako fenomeny zajmujące obecnie ważne miejsce $\mathrm{w}$ świadomości kulturowej mieszkańców Europy. Stownik wspótczesnej kultury krajów języka niemieckiego może zatem pełnić rolę słownika krajoznawczego lub słownika zjawisk socjologicznych, zwłaszcza iż pokaźną część haseł zajmuje problematyka życia politycznego, historii najnowszej czy po prostu współczesnej obyczajowości.

Zdecydowana większość haseł powstała na podstawie literatury drukowanej, często najnowszej. Pojęcia te są $\mathrm{w}$ dużej mierze wynikiem długoletnich badań i zainteresowań naukowych autorów, którzy swoim doświadczeniem i kompetencjami gwarantują wysoki poziom treści opracowanych pojęć. Ogromny udział w tworzeniu haseł słownikowych mieli m.in.: Marek Zybura (hasła dotyczące historii, polityki, życia literackiego w RFN i NRD, stosunków polsko-niemieckich), Edward Białek (w większości problematyka austriacka), Robert Rduch (historia, kultura i literatura Szwajcarii), Evelyna Schmidt (problematyka enerdowska), Dariusz Wojtaszyn (m.in. wydarzenia sportowe) i Ireneusz Paweł Karolewski (życie polityczne krajów niemieckojęzycznych). Innych ciekawych opracowań 
dostarczyli uznani w świecie kultury badacze, wśród których należy wymienić m.in. Joannę Jabłkowską, Andrzeja Gwóździa, Andrzeja Dębskiego, Gabrielę Ociepę, Stefana H. Kaszyńskiego, Daniela Pietrka, Kalinę Kupczyńską, Elżbietę Opiłowską czy Magdalenę Saryusz-Wolską. Może cieszyć to, iż słownik zawiera tak wiele cennych informacji o fenomenach kultury szwajcarskiej, w Polsce często nieznanej (w przeciwieństwie do kultury Niemiec i Austrii). Zapewne $\mathrm{z}$ dużym zainteresowaniem polski czytelnik zapozna się z hasłami dotyczącymi kina i filmu (np. Filmowe wizerunki III Rzeszy, Filmy królicze, Kino migrantów, Kino szwajcarskie), teatru czy sztuk plastycznych, bowiem w obliczu wszechobecnej amerykanizacji te właśnie dziedziny życia kulturalnego krajów niemieckojęzycznych wydają się w obecnym społeczeństwie nieco marginalizowane.

Dużą wartością omawianego tomu są liczne odniesienia do polsko-niemieckich relacji $\mathrm{w}$ kulturze. Znajdziemy tu zatem m.in. informacje na temat sygnowanej przez Niemiecki Instytut Kultury Polskiej (Deutsches Polen-Institut) serii wydawniczej Biblioteka Polska, powstałej z inicjatywy Karla Dedeciusa i popularyzującej twórczość polskich autorów od średniowiecza do czasów współczesnych. Sama historia instytutu i jego zasługi w procesie budowania właściwych stosunków polsko-niemieckich są ciekawie opisane przez Marka Zyburę, który oprócz wspomnianej serii wydawniczej wymienia inne ważne projekty realizowane przez placówkę w Darmstadzie: siedmiotomową antologię literatury polskiej XX wieku łącznie ze słownikiem pisarzy i obszernym komentarzem dotyczącym historii literatury polskiej (Panorama der polnischen Literatur des 20. Jahrhunderts), a także czterotomową bibliografię do historii relacji polsko-niemieckich (Deutsch-polnische Beziehungen in Geschichte und Gegenwart.
Bibliographie, por. s. 258). Marek Zybura zwraca również uwagę na zmianę profilu działalności instytutu po śmierci Karla Dedeciusa i objęciu stanowiska dyrektora przez Dietera Bingena - „na pierwszy plan [...] wysunęły się zagadnienia promocji nauki polskiej, studia społeczno-polityczne i gospodarcze oraz zagadnienia edukacji szkolnej” (s. 258), m.in. dzięki zaangażowaniu Matthiasa Kneipa i Manfreda Macka.

Godnym odnotowania hasłem jest szkic Hansa-Christiana Trepte o historii studiów polonistycznych i slawistycznych w krajach języka niemieckiego. Trepte sięga do początków lektoratu języka polskiego na uniwersytecie w Lipsku (XVII wiek) i wymienia najważniejsze postacie zajmujące stanowiska lektorów na uniwersytetach niemieckich, austriackich i szwajcarskich na przestrzeni XVIII i XIX wieku. Autor szkicu dostrzega zainteresowanie slawistyką w RFN po II wojnie światowej, chociaż - jak przyznaje - „studia polonistyczne możliwe były tylko w ramach slawistyki ogólnej jako kierunek drugi lub poboczny" (s. 304). Dopiero w latach 70. i 80. XX wieku, gdy relacje polsko-niemieckie uległy poprawie, można dostrzec wzmożone zainteresowanie językiem polskim, wynikiem czego było utworzenie w 1983 roku „Mainzer Polonicum” na Uniwersytecie im. Johanna Gutenberga w Moguncji (s. 304). Inaczej sprawa wyglądała w NRD: ze względów politycznych dominującym kierunkiem slawistycznym była rusycystyka, jednak katedry literatury i języka polskiego zostały powołane do życia w Berlinie Wschodnim, Lipsku i Greifswaldzie. W kolejnych latach po zjednoczeniu Niemiec sytuacja polonistyk na zachód od Odry uległa pogorszeniu - Trepte wśród powodów wymienia m.in. politykę oszczędnościową na uczelniach, której ofiarą stały się mniejsze kierunki, w tym właśnie polonistyka, mająca długie tradycje w życiu akademickim Niemiec. Autor podaje przy 
tym dane z ostatnich lat: „Jeszcze w 2006 r. ponad 40 uniwersytetów miało $\mathrm{w}$ ofercie slawistykę z uwzględnieniem polonistyki (czasem tylko $\mathrm{w}$ formie lektoratu, czasem również z zajęciami z literatury i kultury polskiej), natomiast w 2015 r. ich liczba spadła poniżej 30. Studia polonistyczne przede wszystkim $\mathrm{w}$ ramach slawistyki zachodniosłowiańskiej możliwe są jeszcze przede wszystkim w Berlinie, Lipsku, Moguncji i Poczdamie. Pozytywnym faktem jest wprowadzenie w 2008 r. na Uniwersytecie Lipskim języka polskiego jako kierunku nauczycielskiego" (s.305).

W słowniku nie zabrakło również nawiązań do innych ważnych instytucji i czasopism związanych z życiem kulturalnym, mających duży wpływ na promocję kultury i języka niemieckiego w Polsce - Instytutu Goethego, Instytutu Języka Niemieckiego (Institut für Deutsche Sprache), Niemieckiej Centralnej Wymiany Akademickiej (Deutscher Akademischer Austauschdienst) czy Niemieckiej Akademii Języka i Literatury (Deutsche Akademie für Sprache und Dichtung), której jedynym członkiem z Polski, jak zauważa Daniel Pietrek (s. 252), jest toruński profesor germanistyki - Leszek Żyliński. Redaktorzy podkreślają również ważną rolę, jaką od 1987 roku odgrywa w relacjach polsko-niemieckich kwartalnik „Dialog”, wydawany od 1993 roku w obu językach.

O promocji Polski i polskich twórców w krajach niemieckiego obszaru językowego czytelnik może dowiedzieć się z wielu innych szkiców: Kalina Kupczyńska wspomina $\mathrm{w}$ haśle Wespennest. Zeitschrift für brauchbare Texte und Bilder (s. 368), iż jeden $\mathrm{z}$ numerów austriackiego czasopisma „Wespennest” został poświęcony autorkom z Polski (Tokarczuk, Gretkowska, Filipiak, Janion). Także inne czasopisma i wydawnictwa zajmowały się $\mathrm{w}$ ostatnich latach twórczością polskich pisarzy - „Sinn und
Form" (s. 332) publikował m.in. teksty Miłosza, Szymborskiej, Herberta, Baumana czy Zagajewskiego; w wydawnictwie „Carl Hanser” (s. 379) ukazywały się książki np. Gombrowicza, Leca, Schulza, Miłosza, Zagajewskiego, a w wydawnictwie „Diogenes” (s. 380) - Mrożka i Szczypiorskiego. Zuryski teatr dramatyczny (Schauspielhaus Zürich) wystawiał sztuki Gombrowicza, Mrożka i Iredyńskiego, tam też reżyserowali swoje sztuki Wajda, Dejmek, Jarocki, Swinarski i Axer (s. 330). Także w Zurychu - na deskach Theater am Neumarkt - realizowano przedstawienia polskich twórców: Gombrowicza, Różewicza, Mrożka i Witkacego (s. 353). Edward Białek odnotowuje w swoim tekście poświęconym międzynarodowemu festiwalowi sztuki współczesnej (Styryjska Jesień $w$ Austrii), iż podczas imprez festiwalowych prezentowano dorobek Witolda Lutosławskiego, Andrzeja Dobrowolskiego, Kazimierza Serockiego, Marka Stachowskiego, Krzysztofa Pendereckiego, Zbigniewa Bargielskiego, Zygmunta Krauzego i Aleksandra Lasonia; tam też w spotkaniach autorskich brali udział Sławomir Mrożek i Zbigniew Herbert (s. 338). Twórcy polskiego kina byli nagradzani podczas festiwalu filmowego w Locarno (Kazimierz Kutz, Andrzej Piotrowski, Krzysztof Zanussi, Andrzej Zaorski, Małgorzata Szumowska, Beata Dzianowicz, s. 99); film polski był także promowany m.in. na festiwalach „Filmland Polen” w Hanowerze, Hamburgu i Lubece, „filmPOLSKA” w Berlinie czy innych festiwalach w Oberhausen i Mannheim (s. 101). Robertowi Rduchowi, który przygotował szkic o popularnym serialu kryminalnym Miejsce zbrodni („Tatort”, s. 224), nie umknął fakt, iż w serialowym „tasiemcu” pojawiały się polskie motywy i występowali polscy aktorzy (Cezary i Radosław Pazurowie, Marek Kondrat, Agata Buzek).

Warto również zauważyć, że dużą popularnością w Niemczech i Austrii cieszą się 
pisarze urodzeni w Polsce, którzy obecnie mieszkają w krajach niemieckojęzycznych i tworzą w języku niemieckim. Agnieszka Palej wymienia w swoim tekście poświęconym literaturze (i)migracyjnej (s. 199) takich autorów, jak: Artur Becker, Sabrina Janesch, Radek Knapp, Dariusz Muszer, Matthias Nawrat i Adam Soboczynski, przybliżając krótko problematykę najważniejszych ich utworów.

Stownik wspótczesnej kultury krajów ję$z y k a$ niemieckiego to bardzo udane przedsięwzięcie na rynku wydawniczym, stanowiące kompendium wiedzy o fenomenach szeroko rozumianej kultury krajów niemieckojęzycznych. Owszem, można zastanawiać się, czy dany krąg tematyczny nie powinien być uzupełniony o dodatkowe hasła (notabene zabrakło w słowniku haseł dotyczących muzyki), ale należy przypuszczać, że zostaną one przedstawione w kolejnych tomach. Zdecydowanie omawiana publikacja pod redakcją Krzysztofa Ruchniewicza i Marka Zybury powinna znaleźć odbiorców nie tylko wśród studentów germanistyki, niemcoznawstwa, kulturoznawstwa czy europe- istyki, lecz także może być skierowana do czytelnika niezwiązanego z życiem akademickim.

\section{Bibliografia}

Karolak, Czesław, Wojciech Kunicki, Hubert Orłowski 2015. Dzieje kultury niemieckiej. Warszawa: Wydawnictwo Naukowe PWN.

Mazur, Zbigniew, Hubert Orłowski, Maria Wagińska-Marzec 2013. Kultura zjednoczonych Niemiec. Wybrane problemy. Poznań: Instytut Zachodni.

Niemcy współczesne. Zarys encyklopedyczny 1999. Poznań: Instytut Zachodni.

Orłowski, Hubert [et al.] (red.) 1997. Stownik twórców kultury niemieckojęzycznej. Poznań: Wydawnictwo Poznańskie.

Ruchniewicz, Krzysztof, Marek Zybura (red.) 2019. Stownik wspótczesnej kultury krajów języka niemieckiego. T. 1. Poznań: Wydawnictwo Nauka i Innowacje.

Zybura, Marek (red.) 1996. Pisarze niemieckojęzyczni XX wieku. Leksykon encyklopedyczny PWN. Warszawa: Wydawnictwo PWN. 